\title{
Teachers' emotional intelligence and its relation with classroom discipline strategies based on teachers and students' perceptions
}

\begin{abstract}
The purpose of the study is to analyze level of emotional intelligence of teachers employed in the government secondary schools in Malaysia based on selected demographic variables and how they relate to studentsôperception and also on the classroom strategies used. The sample of the study comprises of 203 teachers and 2147 students. The findings of the study showed that there was significant relationship between teachers and studentsô perceptions of the teachersô classroom discipline strategies. The study also revealed that there were no significant differences in the teachersôemotional intelligence between teachers of different genders, and there were significant differences found between teachersô emotional intelligence and age groups. Further significant relationship was found between teachersô emotional intelligence and five strategies of classroom discipline (discussion, aggression, recognition or reward, involvement and hinting) and no significant relationship with one strategy (punishment) of classroom discipline.
\end{abstract}

Keyword: Teachers' emotional intelligence; Students perception; Classroom discipline; Demographic variables 